第 1 表 雲母鉄鉣の分離試験結果

\begin{tabular}{l|r|r|r|r|r}
$\mathrm{A}$ グループ \\
\hline \hline 項目
\end{tabular}

能と考号られる。（本試料は非磁性の脈石部分が $\mathrm{Fe}$ 分 を含んでいるので，磁選尾鉱の $\mathrm{Fe}$ 品位の目標を $20 \%$ に そつて試験を行なつている)。 Dグループの $15 \mu$ 以下の 試料は当初は分離対象外のものであつたが試験的に分離 を試みたものである。本分離機の処理量についても検討 を行なつた。試作機では分離コーンを8区画としたが， 試験の結果によると，A，Bグループの粒度で 12 区画に
分割し， C, D グループの粒度では 10 区画とすることが できるので分離機 1 台当りの処理量は $24 \mathrm{hr}$ 当りに换算 すると

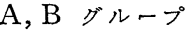
$12 \mathrm{t} / 24 \mathrm{hr}$
C グループ
7. $2 \mathrm{t} / 24 \mathrm{hr}$
$\mathrm{D}$ グループ
$1.0 \mathrm{t} / 24 \mathrm{hr}$

となる。この処理量は従来の乾式交番磁界型磁気分離機 では実現することのできなかつた值である。

以上雲母鉄鉱を中心として行なつた実験結果を述へた が，雲母鉄鉝は磁性がきわ的て弱く，本分離機で処理し 得るもつとも弱いものの限界に位置する試料と考光ら れ，その意味では逆に本分離機の卓越した性能を示す試 験結果とも思考される。これと併行して鉄粉などの分離 試験も実施しているのでこれらの結果についても言及し たい。微粉鉄鉣石のペレタイジング等鉄鉱石の事前処理 が重要な段階になつてきているので本機の用途はかなり 㕕いものと考光られる。（発表には $8 \mathrm{~mm}$ 映写をも併用 し分離状況を説明したい)。

\section{文献}

1）岡村俊彦・八嶋三郎：交流移動磁界の特性々その応用飞関する研 究 (第 1 報), 東北捈山, 第 3 号, 90 94 (昭和26年)

2）大山正 - 八沜三郎 : 同 (第 2 報)，東北㓋山，第 $4 \cdot 5$ 号，34 40 (昭和26年)

3）大山正・分嶋三郎：同 (第 3 報)，東北捈山，第 $4 \cdot 5$ 号，41 46 (昭和26年)

4）大山正・八鳰三郎 : 同 (第 4 報), 東北鉣山，第 8 号，14２1（昭 和28年)

5） 八嶋三郎：同(第 5 報), 東北釷山, 第 9 号, 23 35 (昭和28年)

6）大山正・八嶋三郎 : 同第 6 報, 日鉱誌, 71，115 121（昭和30年）

\title{
1306 浮選機におけるスタビライザの効用について
}

秋田大学鉣山学部教授・工博 林 大 輔(正会員)

\section{1. は じめに}

斜流型のインペラをむつた浅槽・フリ・フロ一式 \#24 相当浮選機（2槽連結）試作品（永田製作所）の実際操 業試験に立会つた。

この試作機は元来ラフアー用とし迅速浮選に適合する ように設計されたものであるが，適当な場所がなかつた ためもあり，ボールミルの直後に切込まれ（東邦亚鉛対 州鉱業所), $\mathrm{Pb}-\mathrm{Zn}$ 鉱, +65mesh $30 \%,-200$ mesh $28 \%$ を含む $45 \sim 60 \%$ 重量濃度の原鉱液に対し，既設の $\mathrm{FW}$ ユニット・セル 2 槽カスケードと比較された。

立会い前における浮選成績は既設機のそれにはるかに 及ばなかつた。著者はその原因を，大量の吸気にたのみ かつ異常な低周速で操業したことにあると考え，立会い に際し若干周速を增加するとともに，インペラに裏羽根 をつけ簡単なスタビライザを槽底に付加することを提案 ・実施したところ，フロス層が厚くなり，かつ安定して 既設機の成績に近づいた。

試作機の実際操業試験に期待するところは，試行錯誤 を通じて適正な䚌拌作用を与えるための機械的諸元の確 定にある。吸気量は必要な限度にとどめるべきである。

本試験の結果では, 低インペラ周速, 低馬力だけがと りえであり，さらに成績を向上するためにはカスケード 構造のもつ近路防止に対応するような部分改造を必要と
するようであり，本試作機の特長として報告するだけの 価值は低いが，スタビライザの効用を再認識させられた という点では著者にとつて貴重な経験であつたので， あ えて私見を述べさせていただく。

\section{2. 試作機の構造と試験条件}

第 1 図に大略の構造・寸法を示す。点線は追加したス タビライザ, 矢印, 曲線はインペラにかかる鉱液の主フ ローパタン。

このパタンは周知のようにワーマンの提唱するもので

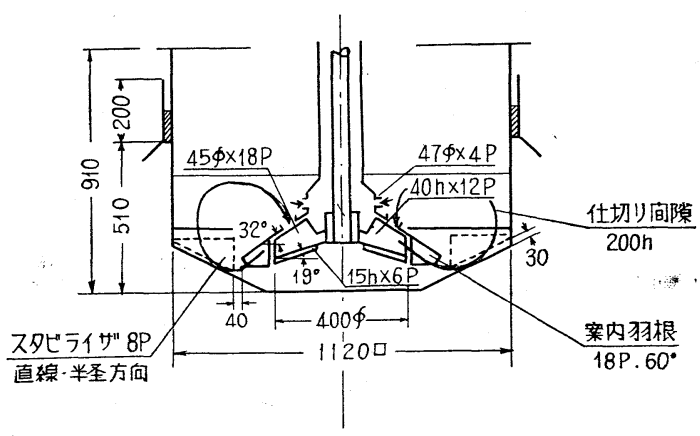

第 1 図 
あり，アジテアの複回路に対して単回路である。多量吸 気・低動力に対する浅槽の有利を保持するためのもので あるが，分離帯々気泡の平均分散の確保が必要である。 ワーマンはこの難点を槽底に植えた曲板型スタビライザ によつて解決している。

試作機の原設計ではインペラ・プロヒルを台形とし， フード・ブッシニと循環孔を併用して，斜流ポンプによ る高水力作用と孔数の調節による広い制御幅を特長とし て単回路を意図したが，案内羽根の吸気性能のよさを尊 重してスタビライザを除いた。基本設計のための基礎実 験では，極低周速の場合を除き，スタビライザの必要を 認めなかつた（裏羽根は粗粒鉱石の場合につけるものと した)。

試験条件としては，比重濃度 $1.38 \sim 1.54$, 品位 $\mathrm{Pb}$ $-2.00 \sim 7.71 \%, \mathrm{Zn}-10.27 \sim 15.30$, 原鉱量 $18 \mathrm{t} / \mathrm{h}$ の原 鉱液について， $\mathrm{Pb}$ 精鉱の品位 $72 \%$ ，採収率 $80 \%$ 以上の 浮選成績を目標とした。

\section{3. 試験の結果と論義}

予備実験の段階で，清水と鉱液について諸元々吸気量 ・動力量との関係を詩細にしている(省略)。この結果過 大そいえる注どの吸気性能をすつていることを確め，周 速を $5.90 \mathrm{~m} / \mathrm{s}$ として立会い前の実際操業試験が実施され
た。ただし，インペラ径 $400 \mathrm{~mm}$ ，液深（サブマーゼン ス） $500 \mathrm{~mm}$ ，循環孔・ブッシュ全開，羽根間隙 $10 \sim 20$ $\mathrm{mm}$ である。

結果はフード板と羽根との間吵の大小，スキンマーの 有無, 浮選剤の種類によつて多少の違いがあるが, $\mathrm{Pb} ・ \mathrm{C}$ を $72 \%$ に限る以上，採収率は $50 \%$ に達しなかつた。外 観的にもフロス層が薄く, 液面の動摇激しくフロス粒度 もきわめて不揃いであつた。

このような結果は，槽底への衝流が十分な強さを示さ ないことによるものであつて，ワーマン機でも経験し た。

そこで周速を $7.5 \mathrm{~m} / \mathrm{s}$ 高めるとともに，吸気量を 0.6 $\mathrm{m}^{3} / \mathrm{m}^{2} \cdot \mathrm{mm}$ に低める措置をとり，さらに分散気泡の微細 化と吐き出し流の旋回成分による偏流の防止を計るた めのスタビライザ板を 8 枚だけ付加して再試験したとこ ろ, $\mathrm{Pb}$ 精鉱の品位と採収率は目標值に達した。羽根間吵 は $20 \mathrm{~mm}$ で，フロス層は $200 \mathrm{~mm}$ となり，かつきわめて 安定した。また周速を $5.9 \mathrm{~m} / \mathrm{s}$ に括としても品位 $75.0 \%$ 採收率 $75.0 \%$ と上つた。な找液深を $600 \mathrm{~mm}$ としてな が，周速にかかわらず，さしたる効果はなかつた。この ような結果はスタビライザの效用の大きいことを示する のと考光られる。 